\title{
PERANCANGAN APLIKASI SEWA LAPANGAN BERBASIS WEB PADA AZIZ FUTSAL KOTA TERNATE
}

\section{DESIGN OF WEB-BASED FIELD RENT APPLICATION IN AZIZ FUTSAL TERNATE CITY}

\author{
Ridwan $^{1}$, Djunaidi Safi ${ }^{2}$, Hairil K.Siradjudin ${ }^{3}$ \\ ${ }^{1,2}$ Prodi Manajemen Informatika \\ Politeknik Sains dan Teknologi Wiratama Maluku Utara \\ ${ }^{3}$ Fakultas Teknik, Prodi Teknik Informatika \\ Universitas Khairun Ternate \\ ewafuraga@gmail.com
}

\begin{abstract}
Abstrak
Aziz Futsal merupakan salah satu tempat penyewaan lapangan futsal yang terdapat di kota Ternate, Penilitian ini bertujuan untuk merancang Aplikasi Sewa Lapangan Berbasis Web Pada Aziz Futsal Kota Ternate agar dapat meningkatkan kinerja dan mempermudah karyawan dalam mengelola data sewa. Metode Analisis dan Pengembangan Sistem menggunakan Model Driven Analisis Berorientasi Objek serta Pengembangannya menggunakan metode sekuensial linier (Waterfall), Sistem ini dirancang dengan Alat bantu UML (Unified Modeling Languange) dan dibuat menggunakan bahasa Pemrograman HTML, CSS, PHP serta database MySQL. Sistem ini dapat mempermudah pelanggan dalam menyewa lapangan dan juga mempermudah karyawan dalam mengelolah data sewa lapangan.
\end{abstract}

Kata kunci: Desain Sistem, Sewa Lapangan, Website

Abstract

Aziz. Futsal is one of the futsal field rent sites in Ternate City, this research aims to create a Web-Based Rental Data Processing System Design in Aziz Futsal Ternate City in order to improve performance and facilitate employees in managing rent data. System Analysis and Development Method using Model Driven Object Oriented Analysis and Development using linear sequential method (Waterfall), This system is designed with UML tools (Unified Modeling Language) and made using HTML, CSS, PHP, and MySQL database programming languages. This system can facilitate customers in renting the field and also make it easier for employees to manage field rent data.

\section{Keywords: Design System, Application, Field Rent, Website}

\section{PENDAHULUAN}

Teknologi pengolahan data yang menggunakan komputer sangat berperan besar pada setiap golongan masyarakat, contohnya saja dalam teknologi komputerisasi jika kita hendak membuat sebuah laporan sekarang bisa menggunakan komputer yang cepat, akurat begitu juga pada penggunaan aplikasi, penggunaan aplikasi pada sebuah perusahaan, sekolah dan organisasi lainnya sangat berpengaruh terhadap kegiatan operasional agar setiap pekerjaan yang dikerjakan menjadi lebih cepat dari 
sebelumnya dan dengan adanya aplikasi akan membantu pengguna dalam menyelesaikan pekerjaannya

Aziz Futzal sebagai salah satu jasa penyedia lapangan futsal yang berada di kelurahan Jati kota Ternate, yang dalam melakukan sewa lapangan dan pengolahan data sewa lapangan belum menggunakan aplikasi dimana proses pengolahan data sewa lapangan yang dilakukan dengan cara menulis pada buku registrasi penyewaan lapangan seperti nama penyewa, kode lapangan, durasi waktu sewa, jam mulai dan jam selesai, sehingga mempelambat kasir atau admin proses mengelolah data sewa lapangan.

Oleh sebab itu dibutuhkan aplikasi yang dapat mengelola data sewa lapangan pada azis futsal sehingga memberikan kemudahan bagi karyawan dalam mengelolah data sewa lapangan. Pengolahan data sewa lapangan menggunakan website, karena website merupakan media informasi yang didalamnya terdapat database yang dapat menampung banyak data sewa, gambar, multimedia yang tersambung ke jaringan internet

\section{Rumusan Masalah}

Berdasarkan latar belakang di atas, yang menjadi permasalahan yang akan dibahas pada penelitian ini adalah bagaimana Merancang Aplikasi Sewa Lapangan pada Aziz Futsal kota Ternate?

\section{LANDASAN TEORI}

\section{Pengertian Sistem}

Menurut McLeod dikutip oleh Yakub (2012:1) mendefiniskan sistem adalah Sekelompok elemen-elemen yang terintegrasi dengan tujuan yang sama untuk mencapai tujuan. Sistem juga merupakan suatu jaringan kerja dari prosedur-prosedur yang saling berhubungan, terkumpul bersama-sama untuk melakukan suatu kegiatan atau untuk tujuan tertentu.

\section{Sistem Informasi}

Hartono (2013:16) menjelaskan Sistem informasi adalah seperangkat komponen yang saling berhubungan, yang bekerja unutk mengumpulkan dan menyimpan data serta mengolahnya menjadi informasi untuk digunakan.

\section{Pengertiian Futsal}

Lhaksana, Justinus, (2011:5) mengartikan futsal (futbol sala) dalam bahasa Spanyol berarti sepak bola dalam ruangan merupakan permainan sepak bola yang di lakukan di dalam ruangan. Permainan ini sendiri di lakukan oleh lima pemain setiap tim berbeda sepak bola konvensional yang pemainnya berjumlah sebelas orang setiap tim. Ukuran lapangan dan ukuran bolanya pun lebih kecil dibandingkan ukuran yang digunakan dalam sepakbola rumput. Futsal adalah permainan bola yang dimainkan oleh dua tim, yang masing-masing beranggotakan lima orang. Tujuannya adalah memasukkan bola ke gawang lawan, dengan memanipulasi bola dengan kaki. Selain lima pemain utama, setiap regu juga diizinkan memiliki pemain cadangan. Tidak seperti permainan sepakbola dalam ruangan lainnya, lapangan futsal dibatasi garis, bukan net atau papan. Dengan berbagai pendapat diatas dapat disimpulkan bahwa futsal adalah permainan beregu yang dimainkan lima lawan lima dalam durasi waktu tertentu dalam sebuah lapangan yang relatif kecil, ukuran bola dan ukuran gawang yang relatif kecil dibandingkan dengan sepakbola, permainan futsal sangat 
menggembirakan dan menarik dimana tim yang memasukkan bola paling banyak ke gawang lawan maka tim itu yang memenangkan permainan.

\section{Pengertian Web}

Menurut Ardhana (2012:3), website adalah suatu layanan sajian informasi yang menggunakan konsep hyperlink, yang memudahkan surfer (sebutan para pemakai komputer yang melakukan browsing atau penelusuran informasi melalui internet).

\section{Pengertian $\boldsymbol{P H P}$}

PHP adalah pemograman (interpreter) adalah proses penerjemahan baris sumber menjadi kode mesin yang dimengerti komputer secara langsung pada saat baris kode dijalankan (Sibero 2012 :49).

\section{Pengertian MySQL}

Menurut Buana (2014:2), MySQL merupakan database server yang paling sering digunakan dalam pemograman PHP.MySQL digunakan untuk menyimpan data di dalam database dan memanipulasi data-data yang diperlukan. Manipulasi data tersebut berupa menambah, mengubah, dan menghapus data yang berada dalam database.

\section{Pengertian Unified Modeling Languange ( UML)}

Unified Modeling Language (UML) adalah salah satu standar bahasa yang banyak digunakan di dunia industri untuk mendefinisikan requirement, membuat analisis dan desain, serta menggambarkan arsitektur dalam pemrograman berorientasi objek. UML merupakan bahasa visual untuk pemodelan dan komunikasi mengenai sebuah sistem dengan menggunakan diagram dan teks-teks pendukung.

UML muncul karena adanya kebutuhan pemodelan visual untuk menspesifikasikan, menggambarkan, membangun, dan dokumentasi dari sistem perangkat lunak $U M L$ hanya berfungsi untuk melakukan pemodelan. Jadi penggunaan $U M L$ tidak terbatas pada metodologi tertentu, meskipun pada kenyataannya $U M L$ paling banyak digunakan pada metodologi berorientasi objek (Rosa A.S dan M. Shalahudin, 2014:133).

\section{Use Case Diagram}

Rosa dan M. Shalahudin (2014:155), use case atau diagram use case merupakan pemodelan untuk kelakuan (behavior) sistem informasi yang akan dibuat. Use case mendeskripsikan sebuah interaksi antara satu atau lebih aktor dengan sistem informasi yang akan dibuat. Secara kasar, use case digunakan untuk mengetahui fungsi apa saja yang ada di dalam sebuah sistem informasi dan siapa saja yang berhak menggunakan fungsi-fungsi itu.

\section{Class Diagram}

Rosa dan M. Shalahudin (2014:141) diagram kelas atau class diagram menggambarkan struktur sistem dari segi pendefinisian kelas-kelas yang akan dibuat untuk membangun sistem. Kelas memiliki apa yang disebut atribut dan method atau operasi. Berikut penjelasan atribut dan method:

1. Atribut merupakan variable-variabel yang dimiliki oleh suatu kelas.

2. Operasi atau method adalah fungsifungsi yang dimiliki oleh suatu kelas

\section{METODE PENELITIAN}


1. Wawancara adalah teknik 1. Laptop Accer Aspire V5 pengumpulan data yang dilakukan dengan cara memberikan seperangkat pertanyaan atau pernyataan kepada salah satu karyawan yang dijadikan responden untuk dijawabnya.

2. Observasi dan Dokumentasi di dalam sistem pengolahan data sewa lapangan ini penulis juga menggunakan data sekunder sebagai acuan yaitu data yang diperoleh dari mengumpulkan dan mempelajari data / informasi melalui observasi dan dokumentasi dalam melakukan penelitian langsung ke objek yang diteliti.

3. Metode Analisys System menggunakan Model Driven Analisys berorientasi objek dengan alat bantu UML dan Pengembangan Sistem menggunakan Model Waterfall serta alat uji sistem menggunakan model Blackbox

\section{Alat dan Bahan yang digunakan}

Alat yang digunakan dalam tugas akhir ini adalah seperangkat komputer yang dilengkapi perangkat lunak pendukung diantaranya Alat bantu Sofware yang digunakan adalah :

1. Sistem Operasi Windows 10 ultimate digunakan sebagai sistem operasi dalam penelitian ini.

2. Microsoft Office word 2010 digunakan untuk penyusun laporan penelitian.

3. Microsoft Visio 2016 untuk membuat gambar alur program.

4. Notepad++ digunakan untuk editor dalam merancang bahasa pemrograman website.

5. CSS, PHP, HTML digunakan sebagai bahasa pemrograman yang dipakai dalam website.

Alat bantu Hadware yang digunakan adalah : 


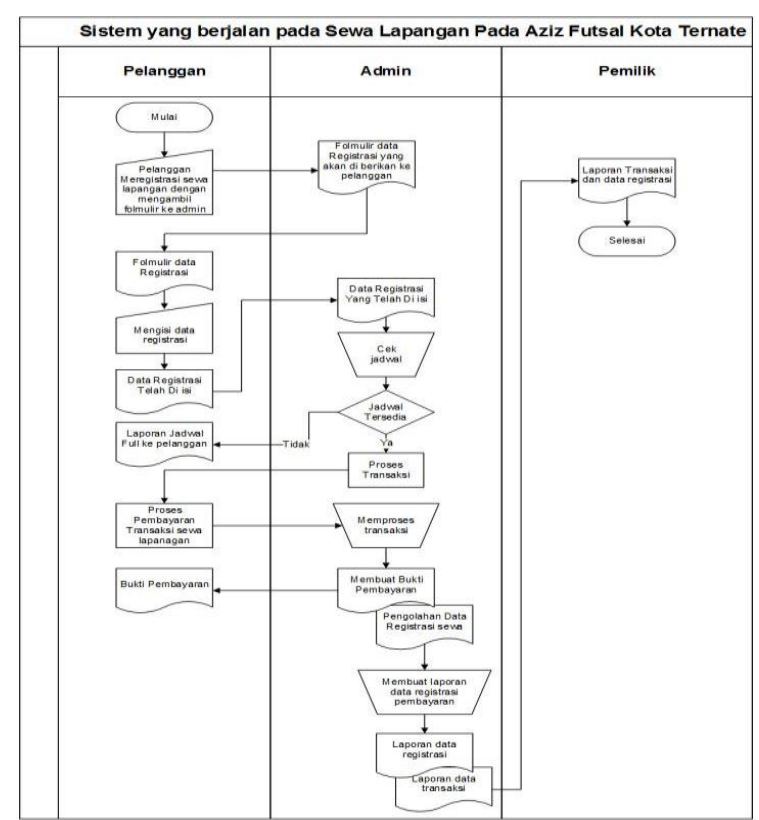

Gambar 2. Sistem yang berjalan

\section{Rancangan System yang Diusulkan}

Dalam sistem yang diusulkan pada Aziz Futsal Kota Ternate maka pengembangan sistem dengan memanfaatkan kemajuan teknologi informasi perlu dilakukan untuk dapat memberi kemudahan bagi karyawan dalam megelola data sewa lapangan

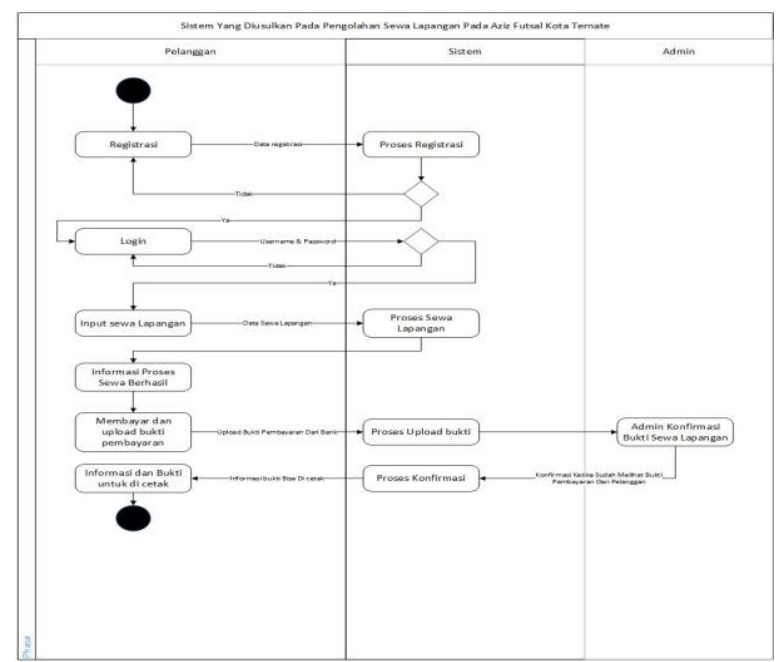

Gambar 3. Flowchart Sistem Yang

Diusulkan

\section{Kebutuhan Fungsional}

Kebutuhan fungsional adalah kebutuhan - kebutuhan yang memiliki keterkaitan langsung dengan sistem. Kebutuhan fungsional dari sistem ini adalah :

1. Kebutuhan Pelanggan

a. Registrasi dan login

b. Menyewa Lapangan

c. Melihat status pemakaian lapangan

d. Mendapatkan informasi dan bukti sewa pada histori

e. Upload bukti pembayaran

f. Cetak bukti pembayaran

2. Kebutuhan Administrator
a. Melakukan Login ke sistem
b. Mengelola Dashboard menu
c. Mengelola Data Lapangan
d. Melihat Data Counter
e. Mengelola Master Booking All
f. Validasi Status Pembayaran
g. Mencetak Laporan Sewa

\section{Kebutuhan Non-Fungsional}

Kebutuhan non-fungsional adalah kebutuhan yang tidak secara langsung terkait dengan fitur tertentu di dalam system, antara lain :

1. Kebutuhan Perangkat Keras

a. Laptop Acer Aspire V 5

b. Sistem dijalankan di Sistem Operasi Windows

c. Database MySQL

d. Notepad++ sebagai editor HTML,PHP, CSS dan MySQL.

e. Sistem dijalankan pada Media Localhost Server Xampp

f. Google Chrome Untuk mejalankan localhost sistem

g. Bahasa Pemograman HTML, PHP, CSS, dan MySQL

\section{PERANCANGAN SISTEM}

\section{Use Case Diagram}

Use Case adalah abstraksi dari sebuah interaksi antara sistem dan actor. Berikut 
ini adalah gambar Use Case Sistem yang diusulkan

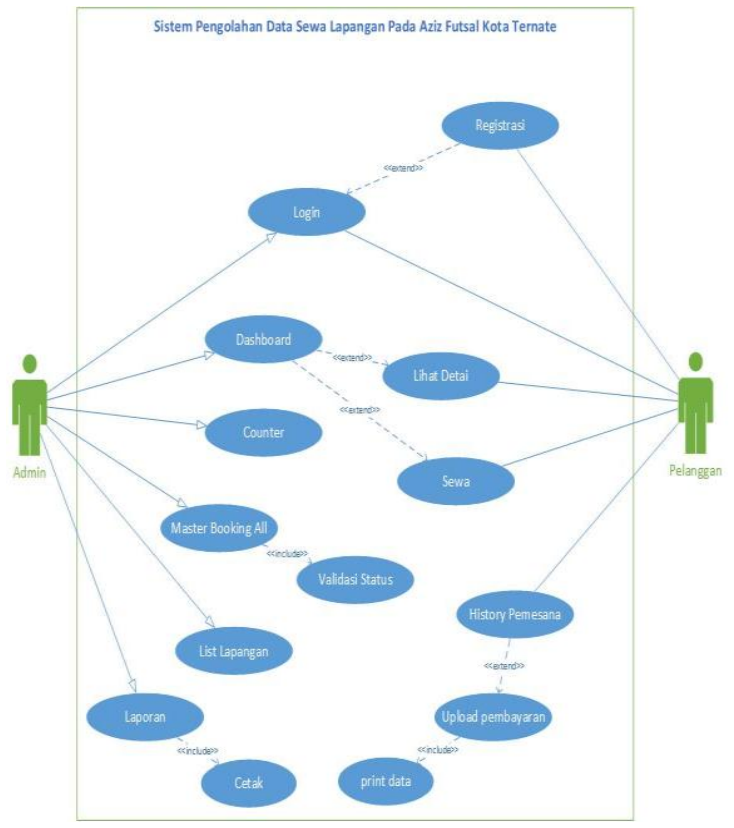

Gambar 4. Use Case Sistem Usulan

\section{Sequence Diagram}

Sequence diagram adalah suatu diagram yang menggambarkan interaksi antar obyek dan mengindikasikan komunikasi di antara obyek-obyek tersebut. Diagram ini juga menunjukkan serangkaian pesan yang dipertukarkan oleh obyek-obyek yang melakukan suatu tugas atau aksi tertentu.

\section{Sequence Login}

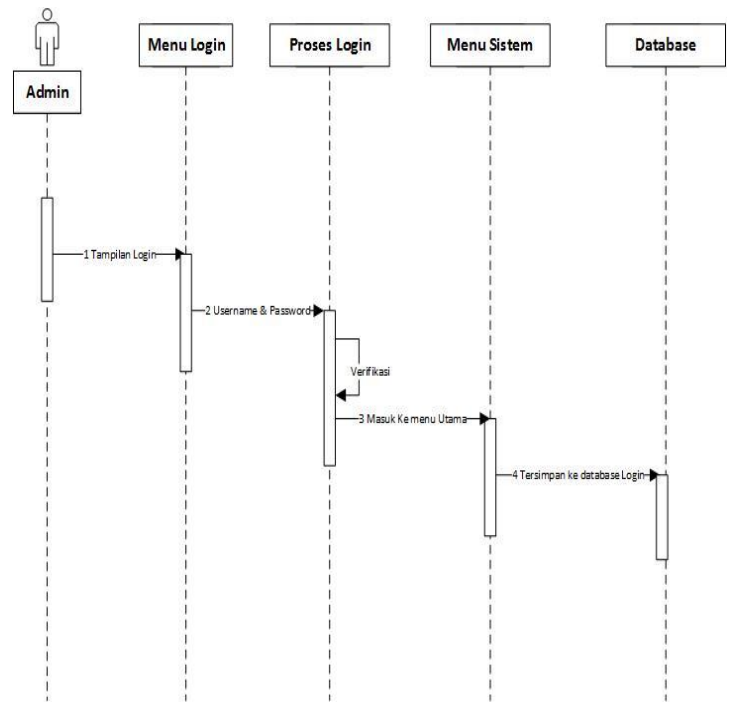

Gambar 5. Sequence Login
Sequence Dashboard Admin

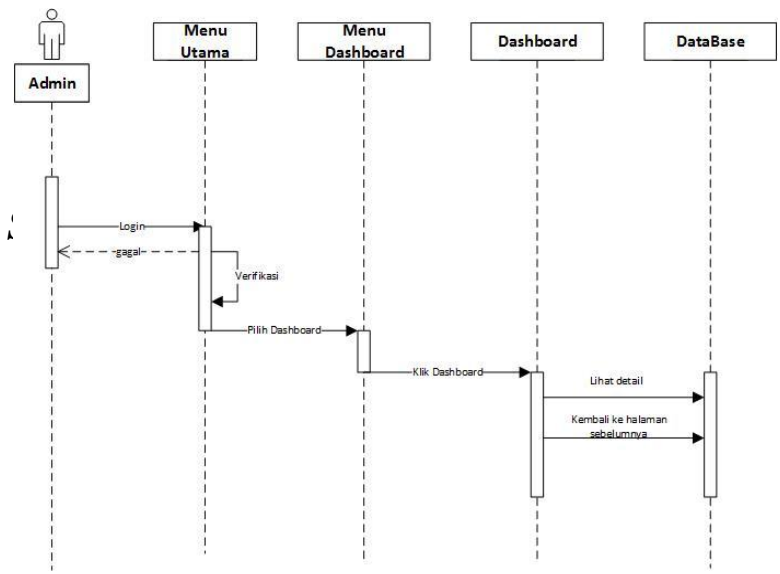

Gambar 7. Sequence Admin

\section{Sequence Master Booking All}

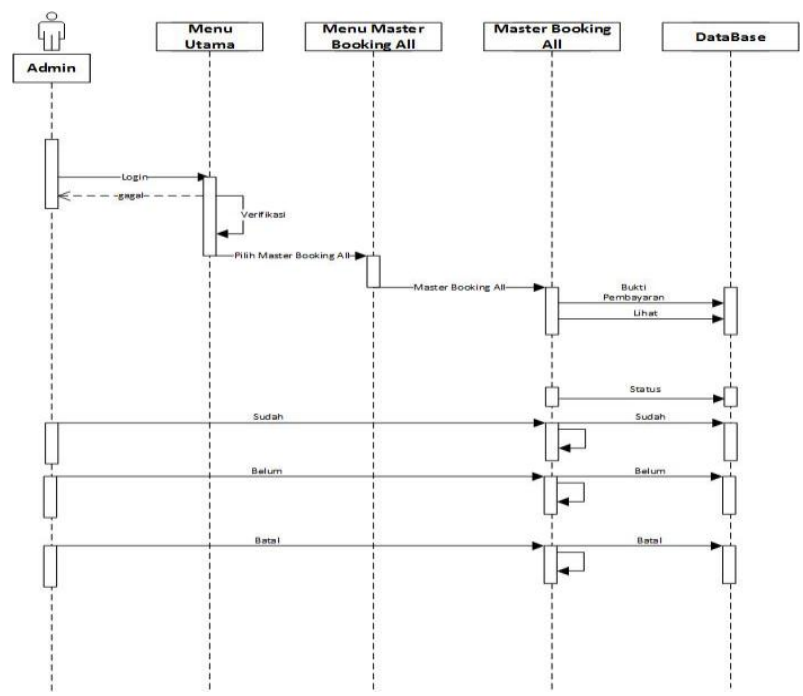

Gambar 8. Sequence Master Booking All

\section{Sequence List Lapangan}

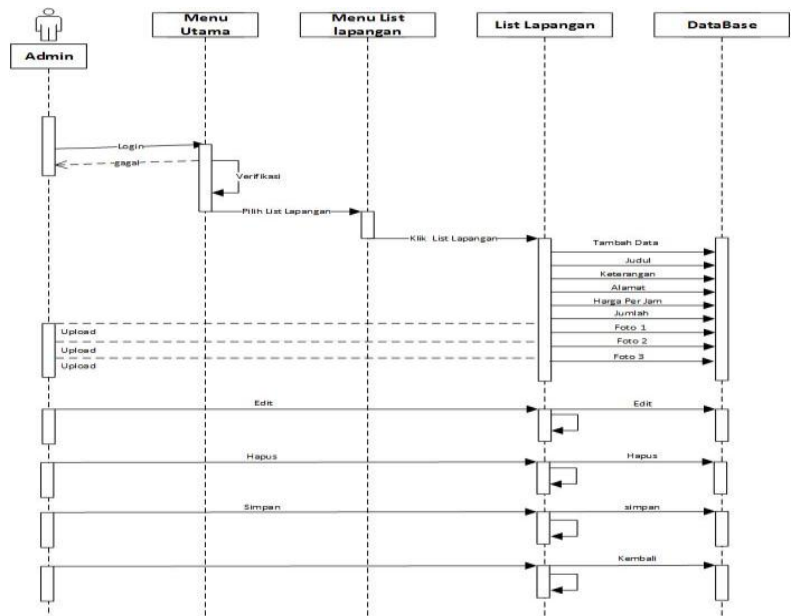

Gambar 9. Sequence List Lapangan 


\section{Sequence Laporan}

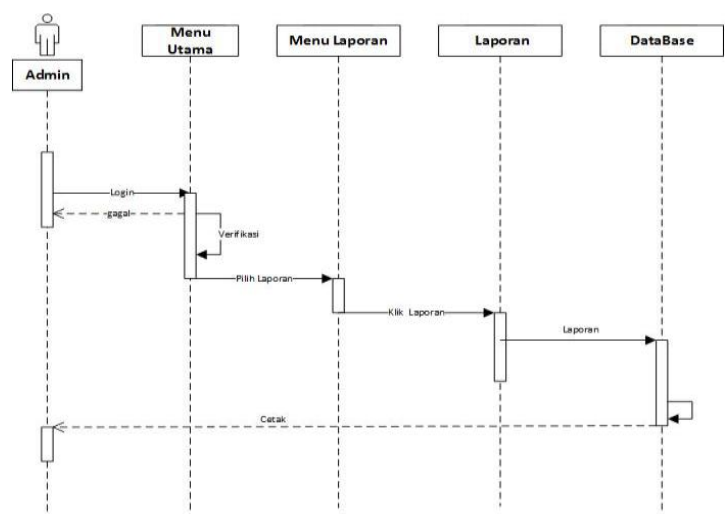

Gambar 10. Sequence Laporan

\section{Sequence Registrasi Pelanggan}

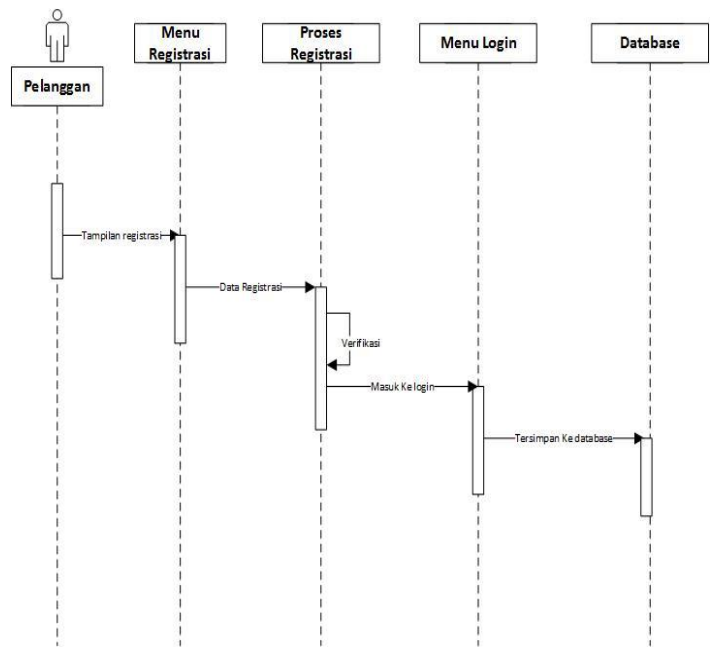

Gambar 11. Sequence Regsitrasi

Pelanggan

\section{Sequence Dashboard Pelanggan}

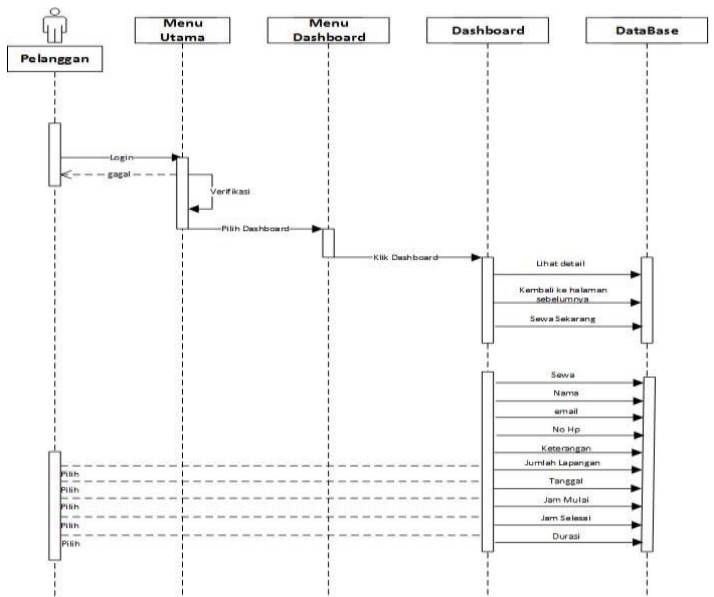

Gambar 12. Sequence Dashboard pelanggan
Sequence History Pemesanan

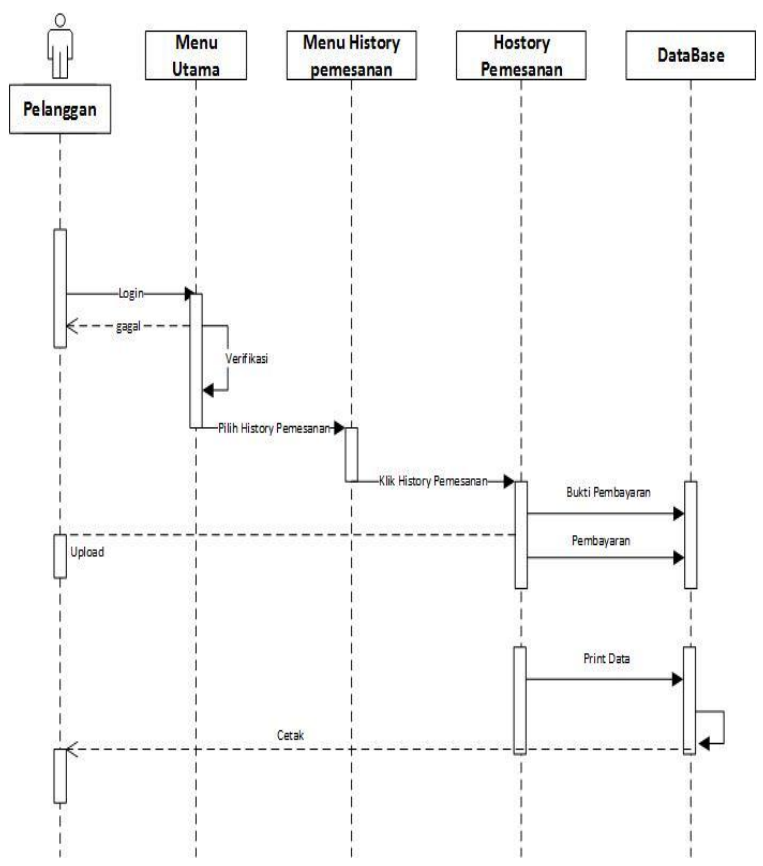

Gambar 13. Sequence Histori pemesanan

\section{Class diagram}

Class Diagram merupakan Diagram relasi pada Database sistem yang digunakan sebagai petunjuk pada database menu saat sistem dijalankan

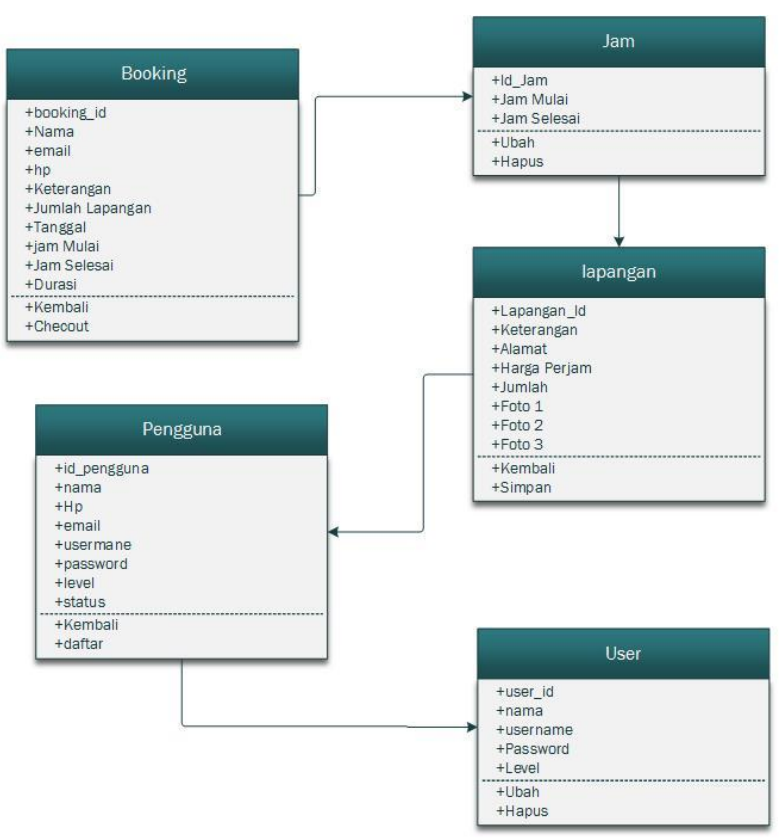

Gambar 14. Class Diagram

\section{Rancangan Struktur Tabel Sistem Rancangan Tabel User}




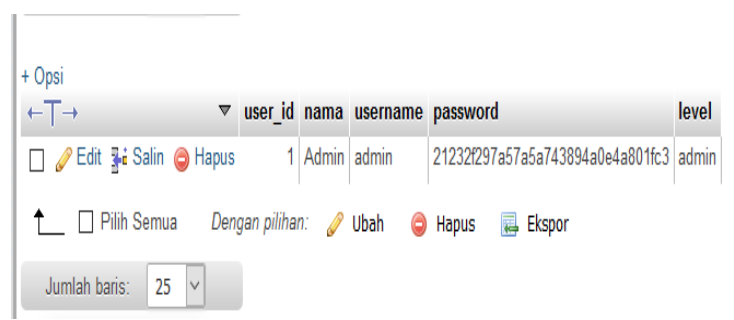

Gambar 15. Tabel User

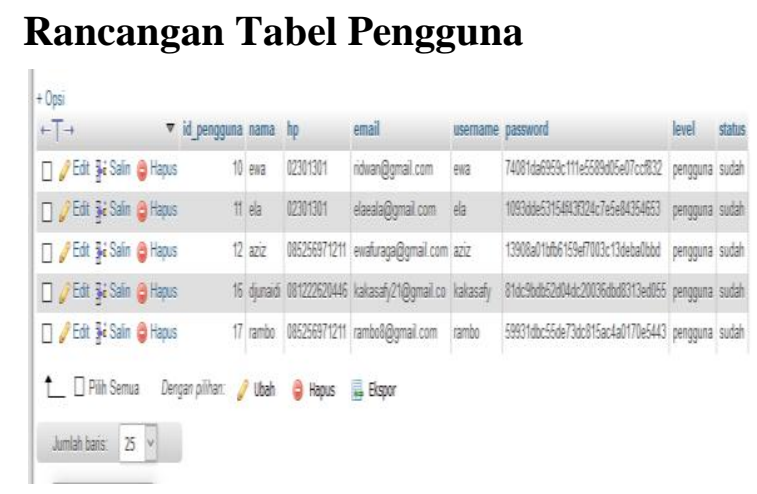

Gambar 16: Tabel Pengguna

\section{Rancangan Tabel Booking}

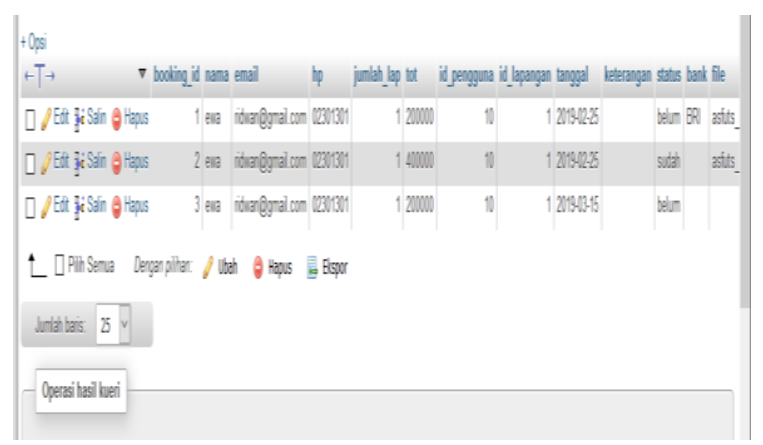

Gambar 17. Tabel Booking

\section{Rancangan Tabel Lapangan}

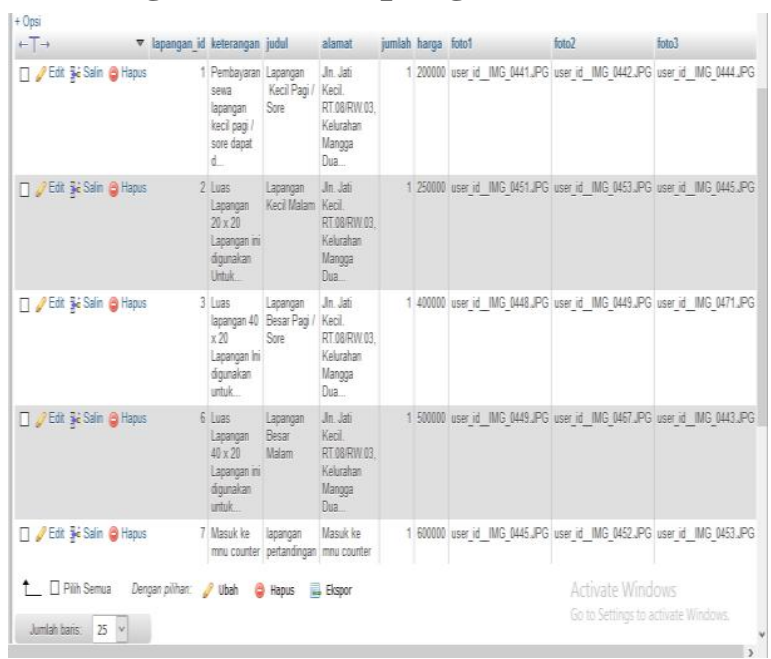

Gambar 18. Tabel Lapangan

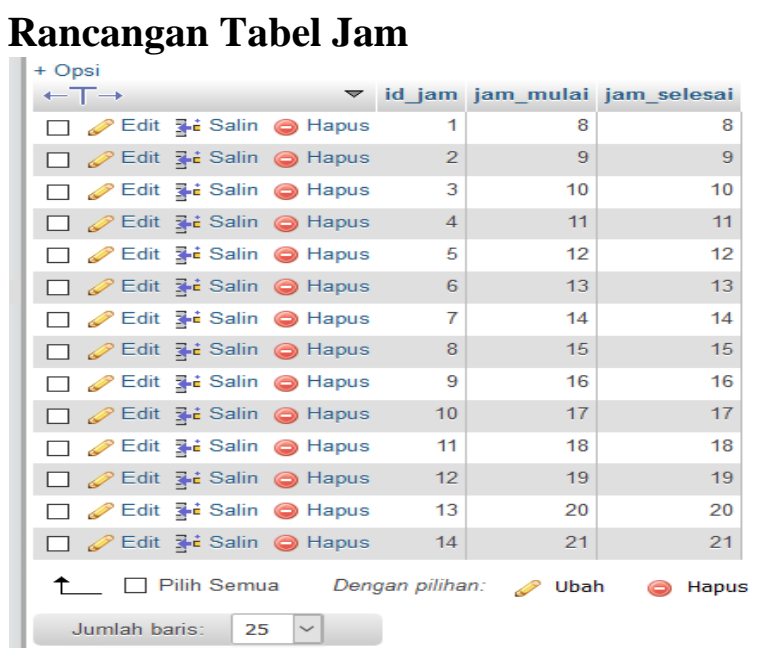

Gambar 19. Tabel Jam

\section{IMPLEMENTASI SISTEM}

Implementasi sistem merupakan hasil perancangan dan desain dari sistem pengolahan data sewa lapangan berbasis pada Aziz futsal yang telah dibuat diatas. Di dalam implemtasi sistem ini nantinya juga akan dijelaskan langkah-langka penggunaan dari tiap-tiap menu yang ada pada sistem pengolahan data sewa lapangan pada Aziz futsal tersebut.

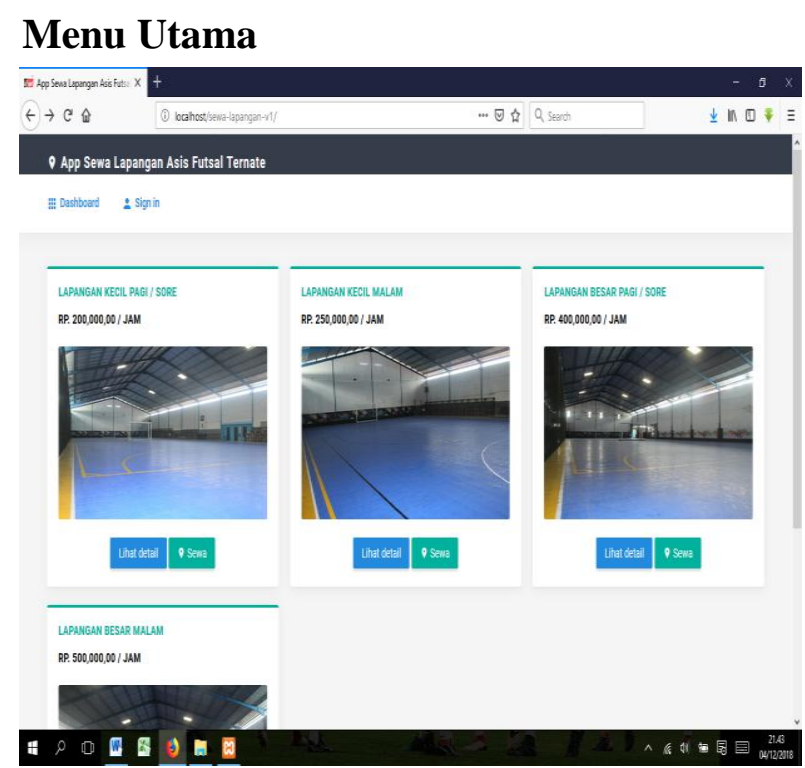

Gambar 20. Tampilan Menu utama 
Halaman Menu Login

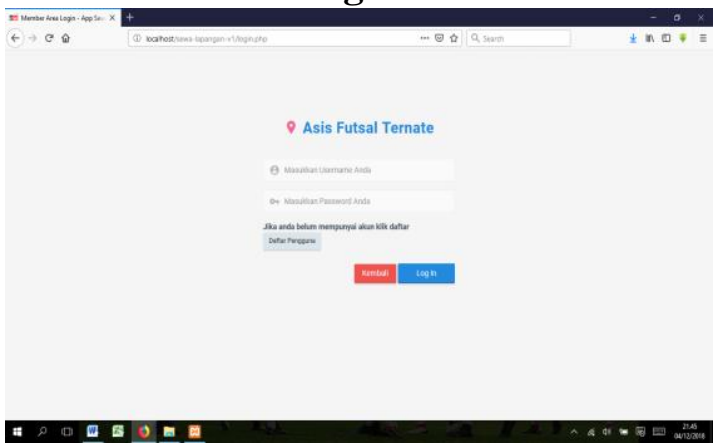

Gambar 21. Menu Login Admin

\section{Halaman Menu Utama Admin}

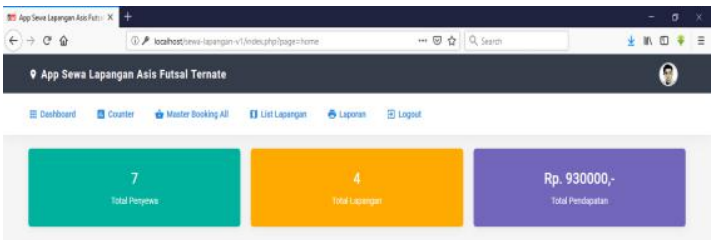

Gambar 22. Menu utama admin

\section{Halaman Menu Dashboard Admin}

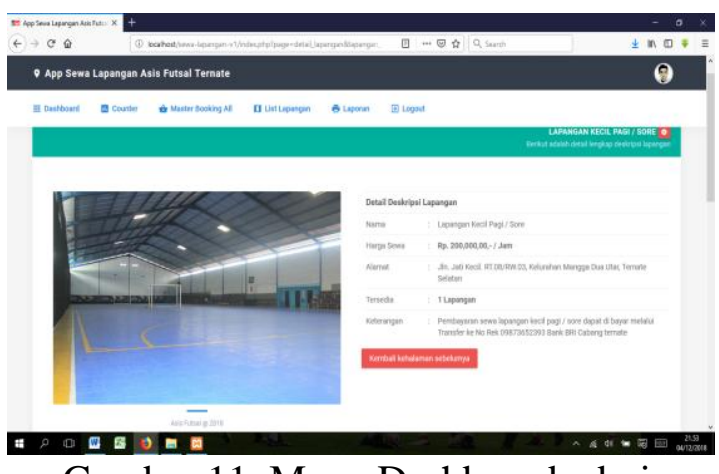

Gambar 11. Menu Dashboard admin

\section{Halaman Menu Counter}

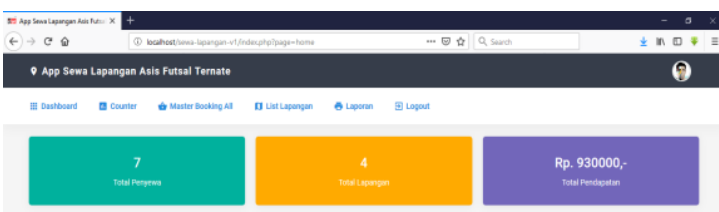

\section{Halaman Master Booking All}

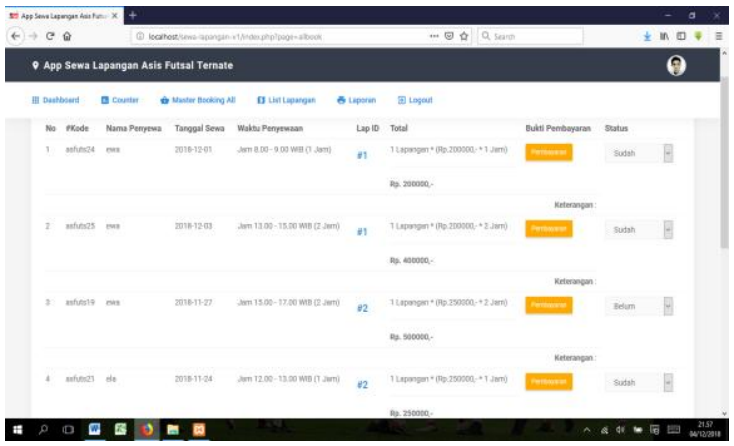

Gambar 24. Master Booking All

\section{Halaman List lapangan}

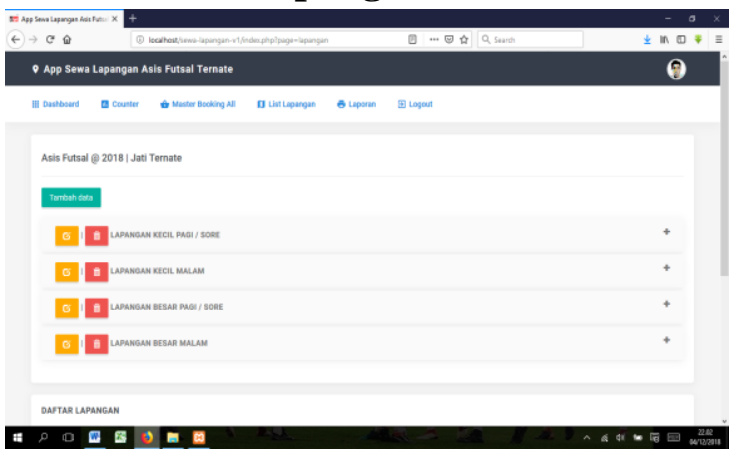

Gambar 25. List Lapangan

\section{Halaman Laporan}

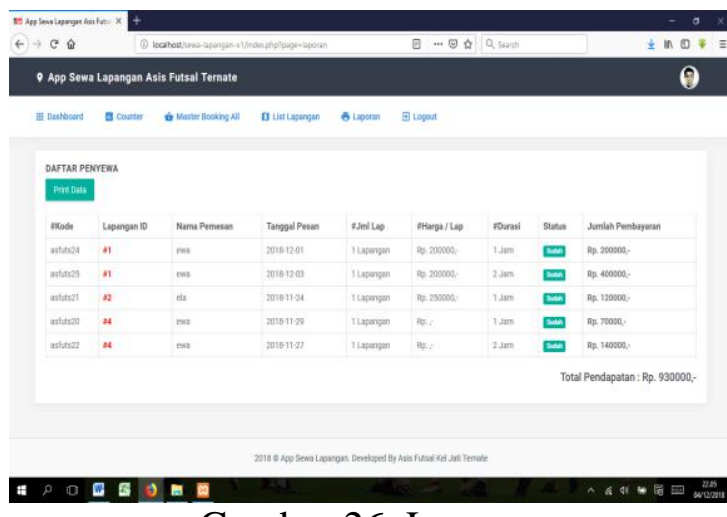

Gambar 26. Laporan

Halaman Registrasi Pelanggan

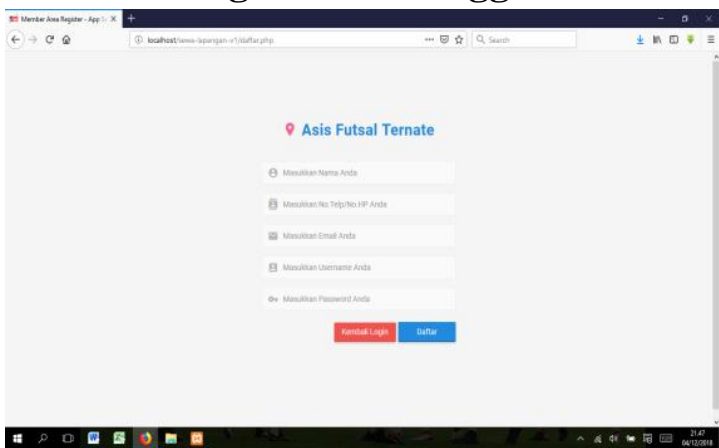

Gambar 27. Registrasi Pelanggan

Volume 4 Nomor 1 | April 2019 


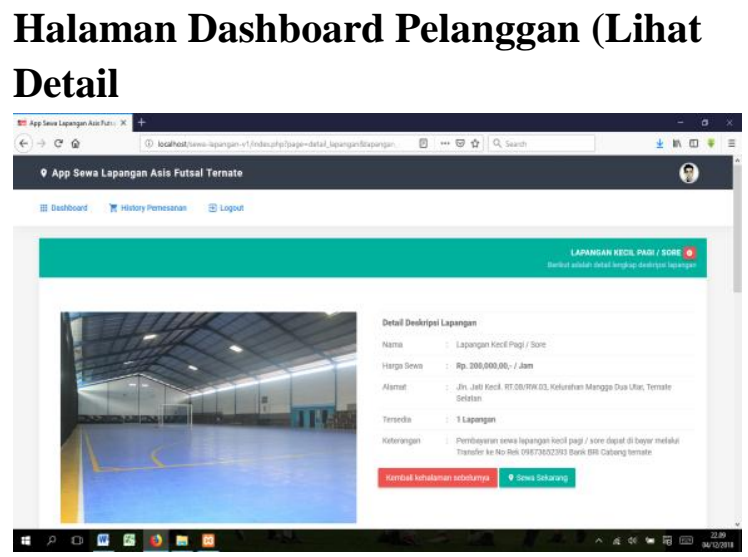

Gambar 28. Dashboard Pelanggan (lihat Detail

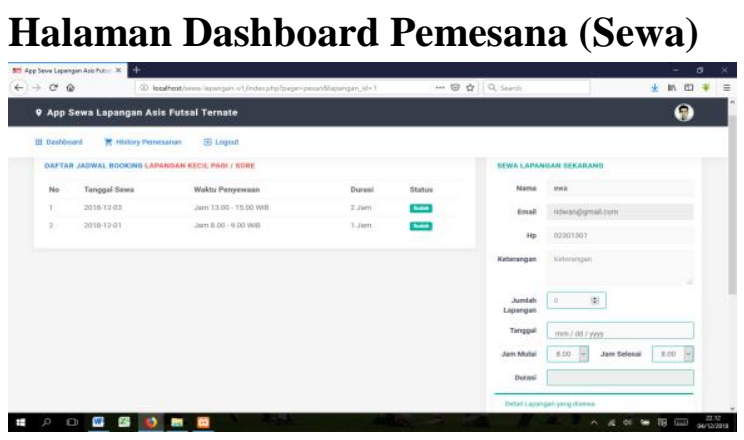

Gambar 29. Dashboard Pelanggan (Sewa)

\section{Halaman Histori Pemesanan}

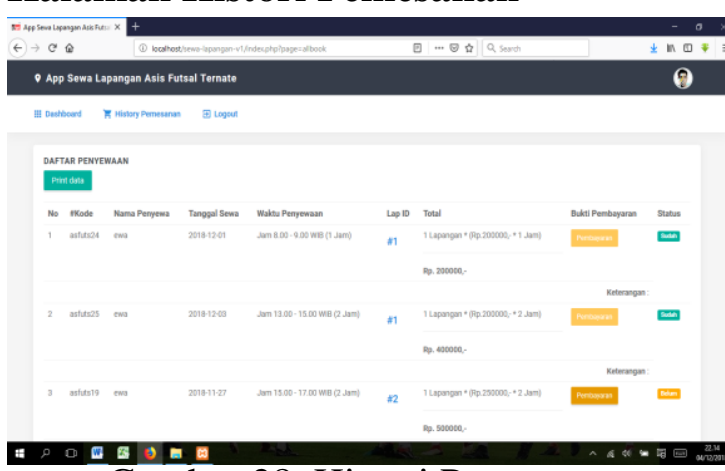

Gambar 28. Histori Pemesanan

\section{Pengujian Sistem Blackbox}

Pengujian yang akan digunakan untuk menguji sistem adalah menggunakan metode pengujian black box. Pengujian black box berfokus pada persyaratan fungsional perangkat lunak.

\section{Pengujian Login}

Tabel 1. Pengujian Login

\begin{tabular}{|c|c|c|c|c|c|}
\hline $\begin{array}{l}\text { Uji } \\
\text { Coba }\end{array}$ & $\begin{array}{l}\text { Status } \\
\text { Aplika } \\
\text { si }\end{array}$ & $\begin{array}{l}\text { Skenar } \\
\text { io } \\
\text { Penguj } \\
\text { ian }\end{array}$ & $\begin{array}{l}\text { Prose } \\
\text { s }\end{array}$ & $\begin{array}{l}\text { Output } \\
\text { Penguj } \\
\text { ian }\end{array}$ & $\begin{array}{l}\text { Keter } \\
\text { anga } \\
\text { n }\end{array}$ \\
\hline $\begin{array}{l}\text { Mengu } \\
\text { ji } \\
\text { Menu } \\
\text { login }\end{array}$ & $\begin{array}{l}\text { Masuk } \\
\text { menu } \\
\text { utama } \\
\text { admin } \\
\text { dan } \\
\text { pelangg } \\
\text { an }\end{array}$ & $\begin{array}{l}\text { Input } \\
\text { userna } \\
\text { me dan } \\
\text { passwo } \\
\text { rd }\end{array}$ & $\begin{array}{l}\text { Berha } \\
\text { sil } \\
\text { melak } \\
\text { ukan } \\
\text { verifi } \\
\text { kasi }\end{array}$ & $\begin{array}{l}\text { Berhasi } \\
1 \text { masuk } \\
\text { ke } \\
\text { Menu } \\
\text { utama }\end{array}$ & $\begin{array}{l}\text { Langs } \\
\text { ung } \\
\text { masu } \\
\mathrm{k} \mathrm{ke} \\
\text { menu } \\
\text { utama }\end{array}$ \\
\hline $\begin{array}{l}\text { Mengu } \\
\text { ji } \\
\text { Menu } \\
\text { login }\end{array}$ & $\begin{array}{l}\text { Masuk } \\
\text { menu } \\
\text { utama } \\
\text { admin } \\
\text { dan } \\
\text { pelangg } \\
\text { an }\end{array}$ & $\begin{array}{l}\text { Input } \\
\text { userna } \\
\text { me dan } \\
\text { passwo } \\
\text { rd }\end{array}$ & $\begin{array}{l}\text { Gagal } \\
\text { melak } \\
\text { ukan } \\
\text { verifi } \\
\text { kasi }\end{array}$ & $\begin{array}{l}\text { Kembal } \\
\text { i ke } \\
\text { tampila } \\
\text { n login }\end{array}$ & $\begin{array}{l}\text { Gagal } \\
\text { login, } \\
\text { usern } \\
\text { ame } \\
\text { dan } \\
\text { passw } \\
\text { ord } \\
\text { yang } \\
\text { anda } \\
\text { masu } \\
\text { kan } \\
\text { salah }\end{array}$ \\
\hline
\end{tabular}

Sumber (Tabel Rancangan Pengujian

Sistem login pada Microsoft Word 2010)

\section{Pengujian Registrasi Pelanggan}

Tabel 2. Pengujian registrasi Pelanggan

\begin{tabular}{|c|c|c|c|c|c|}
\hline $\begin{array}{l}\text { Uji } \\
\text { Coba }\end{array}$ & $\begin{array}{l}\text { Status } \\
\text { Aplik } \\
\text { asi }\end{array}$ & $\begin{array}{l}\text { Sken } \\
\text { ario } \\
\text { Peng } \\
\text { ujian }\end{array}$ & Proses & $\begin{array}{l}\text { Output } \\
\text { Penguji } \\
\text { an }\end{array}$ & $\begin{array}{l}\text { Kete } \\
\text { rang } \\
\text { an }\end{array}$ \\
\hline $\begin{array}{l}\text { Meng } \\
\text { uji } \\
\text { Menu } \\
\text { regist } \\
\text { rasi } \\
\text { pelan } \\
\text { ggan }\end{array}$ & $\begin{array}{l}\text { Masu } \\
\mathrm{k} \\
\text { menu } \\
\text { registr } \\
\text { asi }\end{array}$ & $\begin{array}{l}\text { Input } \\
\text { nama, } \\
\text { no } \\
\text { telpon } \\
\text {, } \\
\text { email, } \\
\text { usern } \\
\text { ame } \\
\text { dan } \\
\text { passw } \\
\text { ord }\end{array}$ & $\begin{array}{l}\text { Berhas } \\
\text { il } \\
\text { melaku } \\
\text { kan } \\
\text { pendaf } \\
\text { taran }\end{array}$ & $\begin{array}{l}\text { Berhasil } \\
\text { dan } \\
\text { masuk } \\
\text { ke menu } \\
\text { login }\end{array}$ & $\begin{array}{l}\text { Daft } \\
\text { ar } \\
\text { berh } \\
\text { asil } \\
\text { diinp } \\
\text { ut, } \\
\text { silak } \\
\text { an } \\
\text { anda } \\
\text { login }\end{array}$ \\
\hline $\begin{array}{l}\text { Meng } \\
\text { uji } \\
\text { Menu } \\
\text { regist } \\
\text { rasi } \\
\text { pelan } \\
\text { ggan }\end{array}$ & $\begin{array}{l}\text { Masu } \\
\mathrm{k} \\
\text { menu } \\
\text { registr } \\
\text { asi }\end{array}$ & $\begin{array}{l}\text { Input } \\
\text { nama, } \\
\text { no } \\
\text { telpon } \\
\text { email, } \\
\text { usern } \\
\text { ame } \\
\text { dan } \\
\text { passw }\end{array}$ & $\begin{array}{l}\text { Gagal } \\
\text { melaku } \\
\text { kan } \\
\text { pendaf } \\
\text { taran }\end{array}$ & $\begin{array}{l}\text { Kembal } \\
\text { i ke } \\
\text { tampila } \\
\text { n } \\
\text { registras } \\
\text { i }\end{array}$ & $\begin{array}{l}\text { Data } \\
\text { haru } \\
\text { s } \\
\text { diisi } \\
\text { deng } \\
\text { an } \\
\text { bena } \\
\text { r, } \\
\text { silka } \\
\mathrm{n}\end{array}$ \\
\hline
\end{tabular}




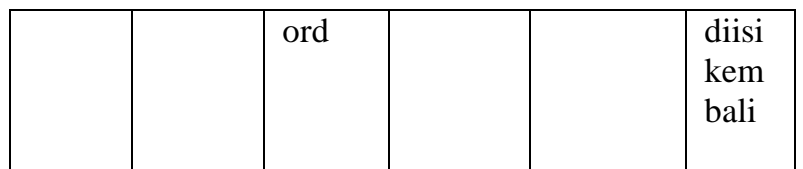

Sumber (Rancangan Pengujian sistem registrasi pada Microsoft Word 2010)

\section{Pengujian Dashboard Admin}

Tabel 3. Pengujian Dashboard Admin

\begin{tabular}{|l|l|l|l|l|l|}
\hline $\begin{array}{l}\text { Uji } \\
\text { Coba }\end{array}$ & $\begin{array}{l}\text { Stat } \\
\text { us } \\
\text { Apli } \\
\text { kasi }\end{array}$ & $\begin{array}{l}\text { Skena } \\
\text { rio } \\
\text { Pengu } \\
\text { jian }\end{array}$ & $\begin{array}{l}\text { Pros } \\
\text { es }\end{array}$ & $\begin{array}{l}\text { Outp } \\
\text { ut } \\
\text { Pengu } \\
\text { jian }\end{array}$ & $\begin{array}{l}\text { Ketera } \\
\text { ngan }\end{array}$ \\
\hline $\begin{array}{l}\text { Meng } \\
\text { uji } \\
\text { Menu }\end{array}$ & $\begin{array}{l}\text { Mas } \\
\text { uk ke } \\
\text { tamp }\end{array}$ & $\begin{array}{l}\text { Klick } \\
\text { lihat } \\
\text { detail } \\
\text { oard } \\
\text { admi } \\
\text { n }\end{array}$ & $\begin{array}{l}\text { ilan } \\
\text { lihat } \\
\text { detai } \\
\text { asil } \\
\text { meli } \\
\text { hat } \\
\text { deskr }\end{array}$ & $\begin{array}{l}\text { Berha } \\
\text { sil } \\
\text { masuk } \\
\text { ke } \\
\text { ipsi } \\
\text { lampil } \\
\text { an } \\
\text { gan }\end{array}$ & $\begin{array}{l}\text { Melihat } \\
\text { gambar } \\
\text { dan } \\
\text { ketail } \\
\text { gan } \\
\text { gan } \\
\text { lapanga } \\
\text { n yang } \\
\text { telah } \\
\text { diinput }\end{array}$ \\
& & & & & \\
& & & & \\
\end{tabular}

Sumber (Rancangan Pengujian Dahsboard pada Microsoft Word 2010)

\section{Pengujian Master Booking All}

Tabel 4. Pengujian Master Booking All

\begin{tabular}{|c|c|c|c|c|c|}
\hline $\begin{array}{l}\text { Uji } \\
\text { Cob } \\
\text { a }\end{array}$ & $\begin{array}{l}\text { Stat } \\
\text { us } \\
\text { Apli } \\
\text { kasi }\end{array}$ & $\begin{array}{l}\text { Skena } \\
\text { rio } \\
\text { Pengu } \\
\text { jian }\end{array}$ & Proses & $\begin{array}{l}\text { Outp } \\
\text { ut } \\
\text { Peng } \\
\text { ujian }\end{array}$ & $\begin{array}{l}\text { Keter } \\
\text { angan }\end{array}$ \\
\hline $\begin{array}{l}\text { Men } \\
\text { guji } \\
\text { Men } \\
\text { u } \\
\text { Mas } \\
\text { ter } \\
\text { Boo } \\
\text { king } \\
\text { All }\end{array}$ & $\begin{array}{l}\text { Mas } \\
\text { uk } \\
\text { ke } \\
\text { daft } \\
\text { ar } \\
\text { peny } \\
\text { ewa }\end{array}$ & $\begin{array}{l}\text { Pilih } \\
\text { bukti } \\
\text { pemba } \\
\text { yaran } \\
\text { dan } \\
\text { pilih } \\
\text { status } \\
\text { sudah }\end{array}$ & $\begin{array}{l}\text { Data } \\
\text { penyew } \\
\text { aMasuk } \\
\text { ke menu } \\
\text { counter } \\
\text { dan } \\
\text { lapaoran }\end{array}$ & $\begin{array}{l}\text { Dafta } \\
\mathrm{r} \\
\text { penye } \\
\text { wa } \\
\text { dapat } \\
\text { diliha } \\
\mathrm{t} \\
\text { pada } \\
\text { lapor } \\
\text { an } \\
\text { dan } \\
\text { menu } \\
\text { count } \\
\text { er }\end{array}$ & $\begin{array}{l}\text { Berhas } \\
\text { il } \\
\text { Diset }\end{array}$ \\
\hline $\begin{array}{l}\text { Men } \\
\text { guji } \\
\text { Men } \\
\mathrm{u} \\
\text { Mas } \\
\text { ter } \\
\text { Boo } \\
\text { king }\end{array}$ & $\begin{array}{l}\text { Mas } \\
\text { uk } \\
\text { ke } \\
\text { daft } \\
\text { ar } \\
\text { peny } \\
\text { ewa }\end{array}$ & $\begin{array}{l}\text { Pilih } \\
\text { bukti } \\
\text { pemba } \\
\text { yaran } \\
\text { dan } \\
\text { pilih } \\
\text { status } \\
\text { belum }\end{array}$ & $\begin{array}{l}\text { Data } \\
\text { pemyew } \\
\text { atidak } \\
\text { Masuk } \\
\text { ke menu } \\
\text { counter }\end{array}$ & $\begin{array}{l}\text { Dafta } \\
\text { r } \\
\text { penye } \\
\text { wa } \\
\text { tidak } \\
\text { ada } \\
\text { dilap } \\
\text { oran } \\
\end{array}$ & $\begin{array}{l}\text { Berhas } \\
\text { il } \\
\text { Diset }\end{array}$ \\
\hline
\end{tabular}

\begin{tabular}{|l|l|l|l|l|l|}
\hline All & & $\begin{array}{l}\text { dan } \\
\text { batal }\end{array}$ & $\begin{array}{l}\text { dan } \\
\text { menu } \\
\text { count } \\
\text { er }\end{array}$ & \\
\hline
\end{tabular}

Sumber (Rancangan Pengujian Sistem Master Booking All pada Microsoft Word 2010)

\section{Pengujian List lapangan}

Tabel 5. Tabel pengujian sistem List lapangan

\begin{tabular}{|c|c|c|c|c|c|}
\hline $\begin{array}{l}\text { Uji } \\
\text { Cob } \\
\text { a }\end{array}$ & $\begin{array}{l}\text { Stat } \\
\text { us } \\
\text { Apli } \\
\text { kasi }\end{array}$ & $\begin{array}{l}\text { Skenario } \\
\text { Pengujia } \\
\text { n }\end{array}$ & $\begin{array}{l}\text { Pros } \\
\text { es }\end{array}$ & $\begin{array}{l}\text { Outp } \\
\text { ut } \\
\text { Peng } \\
\text { ujian }\end{array}$ & $\begin{array}{l}\text { Keter } \\
\text { angan }\end{array}$ \\
\hline $\begin{array}{l}\text { Men } \\
\text { guji } \\
\text { Men } \\
\text { u } \\
\text { List } \\
\text { lapa } \\
\text { ngan }\end{array}$ & $\begin{array}{l}\text { Mas } \\
\text { uk } \\
\text { pada } \\
\text { dafta } \\
\text { r } \\
\text { lapan } \\
\text { gan } \\
\text { tamb } \\
\text { ah } \\
\text { data } \\
\text { lapan } \\
\text { gan }\end{array}$ & $\begin{array}{l}\text { Atur data } \\
\text { lapangan, } \\
\text { input } \\
\text { judul, } \\
\text { keteranga } \\
\text { n,alamat, } \\
\text { harga } \\
\text { perjam, } \\
\text { masukan } \\
\text { foto dan } \\
\text { klik } \\
\text { simpan }\end{array}$ & $\begin{array}{l}\text { Data } \\
\text { lapa } \\
\text { ngan } \\
\text { berh } \\
\text { asil } \\
\text { disi } \\
\text { mpa } \\
\text { n }\end{array}$ & $\begin{array}{l}\text { Data } \\
\text { lapan } \\
\text { gan } \\
\text { masu } \\
\text { k ke } \\
\text { menu } \\
\text { count } \\
\text { er } \\
\text { dan } \\
\text { dashb } \\
\text { oard }\end{array}$ & $\begin{array}{l}\text { Berha } \\
\text { sil } \\
\text { simpa } \\
\text { n data } \\
\text { lapang } \\
\text { an }\end{array}$ \\
\hline $\begin{array}{l}\text { Men } \\
\text { guji } \\
\text { Men } \\
\text { u } \\
\text { List } \\
\text { lapa } \\
\text { ngan }\end{array}$ & $\begin{array}{l}\text { Mas } \\
\text { uk } \\
\text { pada } \\
\text { dafta } \\
\text { r } \\
\text { lapan } \\
\text { gan } \\
\text { ubah } \\
\text { data } \\
\text { lapan } \\
\text { agan }\end{array}$ & $\begin{array}{l}\text { Atur data } \\
\text { lapangan, } \\
\text { ubah } \\
\text { judul, } \\
\text { keteranga } \\
\text { n,alamat, } \\
\text { harga } \\
\text { perjam, } \\
\text { masukan } \\
\text { foto dan } \\
\text { klik } \\
\text { simpan }\end{array}$ & $\begin{array}{l}\text { Data } \\
\text { lapa } \\
\text { ngan } \\
\text { berh } \\
\text { asil } \\
\text { disi } \\
\text { mpa } \\
\text { n }\end{array}$ & $\begin{array}{l}\text { Data } \\
\text { lapan } \\
\text { gan } \\
\text { masu } \\
\text { k ke } \\
\text { menu } \\
\text { count } \\
\text { er } \\
\text { dan } \\
\text { dashb } \\
\text { oard }\end{array}$ & $\begin{array}{l}\text { Berha } \\
\text { sil } \\
\text { ubah } \\
\text { data } \\
\text { lapang } \\
\text { an }\end{array}$ \\
\hline
\end{tabular}

Sumber (Rancangan Pengujian sistem List lapangan pada Microsoft Word 2010)

\section{KESIMPULAN}

Berdasarkan Implementasi dan Pengujian Sistem maka dapat ditarik kesimpulan tentang pembuatan Sistem pengolahan data Sewa lapangan Aziz Futsal Di Kota Ternate diantaranya sebagai Berikut : 1). Sistem ini akan maksimal ketika diakses secara online, 
pelanggan melakukan registrasi, sewa lapangan terus membayarar transaksi lalu diupload dan mendapat bukti sewa lapangan kemudian admin mengkonfirmasi sewa lapangan dari pelanggan. 2). Sistem Pengolahan data sewa berbasis web ini dibuat untuk mempermudah admin dan pelanggan dalam proses sewa lapangan pada sistem.

Dari kesimpulan diatas maka dapat disarankan sebagai berikut: 1). Pemilik Azis Futsal dapat memanfaatkan sistem ini dengan mempublishkan sistem secara online. 2). Pada sistem disarankan memiliki menu jadwal serta desain tampilan antar muka yang interaktif pada halaman beranda

\section{DAFTAR PUSTAKA}

Ardhana, YM Kusuma., (2013), Pemrograman PHP CodeIgniter Blackbox, Jasakom, Jakarta

Buana, I Komang. S. (2014). Jago Pemrograman PHP. Yogyakarta: Penerbit Dunia Komputer.

Dondeti, Jagruthi dan Nidhra, Srinivas. (2012). Black Box And White Box Testing Techniques -A Literature Review, International Journal of Embedded Systems and Applications (IJESA) Vol. 2, No. 2, pp 8-9.

Hartono, B. (2013). Sistem Informasi Manajemen Berbasis Komputer. Jakarta. Rineka Cipta.

Lhaksana, Justinus. (2011). Taktik dan Strategi Futsal Modern. Be Champion. Jakarta

Muharto \& Ambarita, A. (2016). Metode Penelitian Sistem Informasi: Mengatasi Kesulitan Mahasiswa Dalam Menyusun Proposal Penelitian.Yogyakarta. Deepublish.
Raharjo, B. (2011). Belajar Otodidak Membuat Database Menggunakan MySQL. Bandung. Informatika.

Rosa \& Shalahuddin, M. (2013). Rekayasa Perangkat Lunak Terstruktur Dan Berorientasi Objek. Bandung. Informatika.

Sibero, A. F.K. (2013). Web Programming Power Pack. Yogyakarta: Mediakom

Sukamto, R,A., \& Shalahuddin, M., (2014). Modul Pembelajaran Rekayasa Perangkat Lunak, Bandung.

Taufiq R. (2013). Sistem Informasi Manajemen. Konsep Dasar, Analisis dan Metode Pengembangan. Yogyakarta: Graha Ilmu.

Yakub, (2012). Pengantar Sistem Informasi. Yogyakarta. Graha Ilmu.

Maimunah. Hariyansyah. Jihadi, Galu. (2017). Rancang Bangun Sistem Aplikasi Penyewaan Lapangan Futsal Berbasis Web, Seminar Nasional Teknologi Informasi dan Multimedia 2017, STMIK AMIKOM Yogyakarta, 4 Februari 2017, ISSN : 2302-3805

Muhammad, Luthfan Syakur. Indah, Uly Wardati. (2015). Sistem Informasi Penyewaan Lapangan Futsal Pada Grindulu Futsal Pacitan, IJNS Indonesian Journal on Networking and Security - ISSN: 2302-5700 